\title{
KONSEP PEMIKIRAN EKONOMI ISLAM
}

Oleh: A. Muh. Khaerul Isman

Al-Gazali adalah Abhamid Mohamed bin Mohamed bin Mohamed bin Gazali, dimiliki oleh organisasi Islam Hujjah al-Islam, dan lahir di Ghazaleh, sebuah desa dekat kota Kulasan di Iran, pada 450 H / 1056 MAI Ghazali berada di era tersebut kehidupan ekonomi Islam di era feodalisme militer atau perbudakan. Ciri khas era ini adalah aturan kehidupan pertanian, dan kehidupan pertanian selalu diawasi oleh penguasa, dan otoritas ini selalu mengawasi aktivitas para pekerja.

Pada saat yang sama, penguasa berusaha mencari legitimasi tindakannya melalui jalur birokrasi, atau mencari bantuan dari pemuka agama, mengeluarkan fatwa yang membenarkan tindakan tersebut, dan melakukan serangan budaya ketika pemerintah membangun fasilitas pendidikan. Perspektif sejarah ekonomi Islam telah memasuki tahap kedua. Pada tahap ini, motif banyak orang adalah penyebaran korupsi dan penghapusan moral, serta semakin lebar jurang antara si kaya dan si miskin, meski secara keseluruhan keadaan ekonomi umat Islam berada pada taraf kemakmuran.

Perkembangan ekonomi Islam merupakan hal yang tidak bisa di pisahkan dari perkembangan sejarah Islam. Meskipun literatur tidak secara implisit mengatakan keberadaan pemikiran Ekonomi Islam, akan tetapi hal ini akibat dari perkembangan ekonomi Islam yang tidak dipisahkan dari perkembangan sosial kemasyarakatan. ${ }^{1}$

Kondisi sosial ekonomi umat Islam di bagi dalam lima tahap (menurut Peter Gran). Tahap pertama yakni era jahiliyah, dimana ini berlangsung hingga $660 \mathrm{M}$, pada masa ini masih di dominasi corak nomadis. Tahap kedua, yakni pada tahun 660-950 disebut era negaranegara agraris pemberi upeti. Tahap ketiga, yakni antara tahun 9501550 dimana pada era ini aktivitas di dominasi oleh perdagangan.

${ }^{1}$ Winarno, Sejarah Pemikiran Ekonomi Islam di Masa Rasulullah Saw., Jurnal Asy-Syar'iyyah, Vol. 2, No. 1, 2017. 
Tahap keempat, yakni pada tahun 1550-1850 merupakan tahap dimana masyarakat cenderung untuk meninggalkan cara-cara hidup dalam koloni kecil dan membentuk koloni lebih besar dalam bentuk kerajaan. Dan tahap kelima, yakni tahun 1850 hingga sekarang disebut istilah era kapitalisme pinggiran. Al-Ghazali ada dalam masa ekonomi Islam feodal militer. ${ }^{2}$

Al-Gazali mempunyai wawasan yang sangat luas dan mendalam tentang berbagai kesulitan yang timbul dari pertukaran barter dari satu sisi, disisi lain signifikansi uang dalam kehidupan manusia. Sebelumnya telah dikemukakan bagaimana tidak efisiennya jika dilakukan sistem barter. la pun menegaskan bahwa evolusi uang terjadi hanya kesepakatan dan kebiasaan, yakni tidak akan ada masyarakat tanpa pertukaran barang dan tidak ada pertukaran yang efektif tanpa ekuivalensi, dan ekuivalensi demikian hanya dapat ditentukan dengan tepat bila ada ukuran yang sama

${ }^{2}$ Sirajuddin, Konsep Pemikiran Ekonomi Al-Ghazali, Jurnal Laa Maisyir, Volume 3, Nomor 1, Juni 2016. 